\title{
Berberine Protects Human Retinal Pigment Epithelial Cells from Hydrogen Peroxide-Induced Oxidative Damage through Activation of AMPK
}

\author{
Shuai Li ${ }^{1}$, Uma Gaur ${ }^{1}$, Cheong-Meng Chong ${ }^{1}$, Shaofen Lin ${ }^{2}$, Jiankang Fang ${ }^{1}$, Zhiwen Zeng ${ }^{1}$, \\ Haitao Wang ${ }^{3}$ and Wenhua Zheng ${ }^{1,4, *}$ \\ 1 Faculty of Health Science, University of Macau, Taipa, Macau 999078, China; yb67619@umac.mo (S.L.); \\ gaur.uma2906@gmail.com (U.G.); legendhero91@gmail.com (C.-M.C.); yb57646@umac.mo (J.F.); \\ zengzw1122@gmail.com (Z.Z.) \\ 2 State Key Laboratory of Ophthalmology, Zhongshan Ophthalmic Center and School of Pharmaceutical \\ Sciences, Sun Yat-sen University, Guangzhou 510000, China; linshaofen1970@163.com \\ 3 Department of Neuropharmacology and Novel Drug Discovery, School of Pharmaceutical Sciences, \\ Southern Medical University, Guangzhou 510000, China; wht821@smu.edu.cn \\ 4 UM Zhuhai Research Institute, Zhuhai 519000, China \\ * Correspondence: wenhuazheng@umac.mo; Tel.: +853-8822-4919; Fax: +853-8822-2314
}

Received: 28 December 2017; Accepted: 12 March 2018; Published: 12 June 2018

\begin{abstract}
Age-related macular degeneration (AMD) is the leading cause of central vision loss in the elderly with less effective treatment, especially for dry AMD (90\% of AMD). Although the etiology of this disease is not well elucidated, increasing evidences indicate that excessive reactive oxygen species (ROS) impairing the physiological functions of retinal pigment epithelium (RPE) cells may be one of the main causes. Therefore, it could be a great strategy to find some drugs that can effectively protect RPE cells from oxidative damage which is desired to treat and slow the process of AMD. In the present study, a well-known traditional Chinese medicine berberine (BBR) was found to suppress hydrogen peroxide $\left(\mathrm{H}_{2} \mathrm{O}_{2}\right)$-induced oxidative damage in D407 cells, a human RPE cell line. Pre-treatment of D407 cells with BBR significantly suppressed $\mathrm{H}_{2} \mathrm{O}_{2}$-induced cell apoptosis by restoring abnormal changes in nuclear morphology, preventing the decline of mitochondrial membrane potential, reducing lactate dehydrogenase release and inhibiting caspase $3 / 7$ activities induced by $\mathrm{H}_{2} \mathrm{O}_{2}$. Western blot analysis showed that $\mathrm{BBR}$ was able to stimulate the phosphorylation/activation of AMPK in a time- and dose-dependent manner in D407 cells, while treatment of cells with AMPK pathway inhibitor Compound C, or knockdown of the AMPK by specific siRNA blocked the effect of BBR. Similar results were obtained in primary cultured human RPE cells. Taken together, these results demonstrated that BBR was able to protect RPE cells against oxidative stress via the activation of AMPK pathway. Our findings also indicate the potential application of BBR in AMD treatment.
\end{abstract}

Keywords: berberine; age-related macular degeneration; D407 cells; AMPK

\section{Introduction}

One of the most devastating retinal disease is age-related macular degeneration (AMD), which is also the major cause of blindness throughout the world. The prominent characteristic of AMD is the loss of central vision due to the progressive degeneration of the macula [1-3]. The number of AMD patients is predicted to increase two-fold in the coming decades due to an increasingly aged population [4]. The disease can be divided into dry and wet AMD forms and the dry form of the disease is more prevalent accounting for up to $90 \%$ of all cases [5]. Continued intraocular injections 
are the current treatment strategy to prevent progression of wet AMD (10\%) [6]. However, the dry AMD still lacks efficient treatment and calls for the development of effective therapies. Although the mechanisms behind the origin and development of AMD are not fully understood, increasing studies have indicated that chronic inflammation, oxidative stress, and apoptosis might have an important role in the development of dry AMD $[7,8]$. Therefore, discovery of effective candidate drugs which can prevent or delay these injuries are urgently required to treat or slow down the process of dry AMD.

The layer of retinal pigment epithelial (RPE) cells in the macula has been reported to break down or get thin in the dry AMD [9]. RPE is a pigmented monolayer which plays crucial roles in retinal functions [10]. The degeneration of RPE with advancing age causes the death of photoreceptor cells thereby leading to vision loss [11-13]. The retina has been shown to have the highest oxygen consumption in comparison to other tissues, which indicates that the retinal RPE cells are more prone to oxidative stress $[14,15]$. Oxidative damage occurs while reactive oxygen species (ROS) causes lipid peroxidation, oxidation of enzymes, and DNA breakage resulting in irreversible damage to the cells. Increasing studies have suggested that oxidative stress induced by chemical oxidants such as hydrogen peroxide $\left(\mathrm{H}_{2} \mathrm{O}_{2}\right)$ leads to RPE damage and death [16-18]. These findings provide experimental evidences in support of oxidative stress playing a crucial role in RPE degeneration. Some studies have shown that use of additional antioxidants to suppress oxidative stress can avoid oxidative damage and maintain the function of retina [19-21].Therefore, suppressing oxidative stress-induced RPE cell injury may be a potential strategy for delaying the progression of dry AMD.

Previously, we successfully created an $\mathrm{H}_{2} \mathrm{O}_{2}$-induced RPE cell injury model with D407 cells to screen potential protectants from a library of active components of various Chinese medicines [22]. Berberine (BBR, the structure of BBR is shown in Figure 1A), is a natural alkaloid compound derived from Coptis chinensis, is found to efficiently increase the D407 cells' viability from the damage caused by $\mathrm{H}_{2} \mathrm{O}_{2}$ exposure between various Chinese medicines in our lab. For decades, BBR has been widely used in China as a medication for diarrhea. Various clinical studies conducted in the recent years have shown its therapeutic potential in many types of chronic diseases [23]. Accumulated studies suggested that BBR is endowed with several pharmacological activities, including anti-tumor activity [24], cardiovascular-protective actions [25,26], anti-inflammatory effects [27] and it has also been found to inhibit the expression of inflammatory cytokines in ARPE-19 cells cultured in the presence of TNF- $\alpha$ [28]. In addition, BBR also exhibited various other biological effects such as glucose regulation and lipid metabolism in vitro and in vivo [29,30]. However, whether BBR exerts any protective effects against $\mathrm{H}_{2} \mathrm{O}_{2}$ insult in RPE cells and the underlying mechanisms are still unknown.

In this study, we found that the protective effects of BBR against $\mathrm{H}_{2} \mathrm{O}_{2}$-induced oxidative damage in D407 RPE cells and primary cultured hRPE cells were executed via restoring the abnormal changes in nuclear morphology, intracellular ROS, mitochondrial membrane potential, and caspase activation. We also demonstrated that the protective effect of BBR is mediated via the AMPK pathway. These findings suggested that BBR administration might be considered as a potential therapeutic approach for the treatment of AMD.<smiles>COc1ccc2cc3[n+](cc2c1OC)CCc1cc2c(cc1-3)OCO2</smiles>

(A)

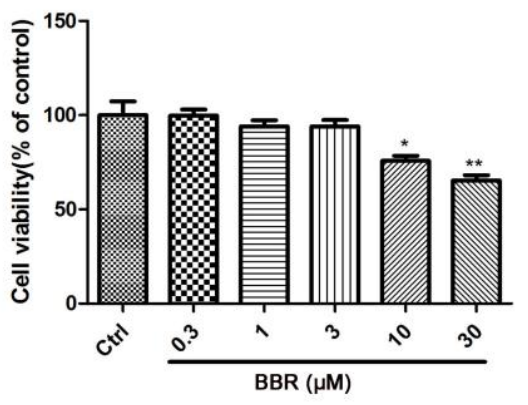

(B)

Figure 1. Cont. 


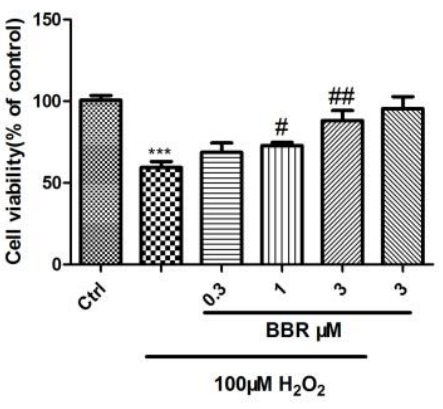

(C)

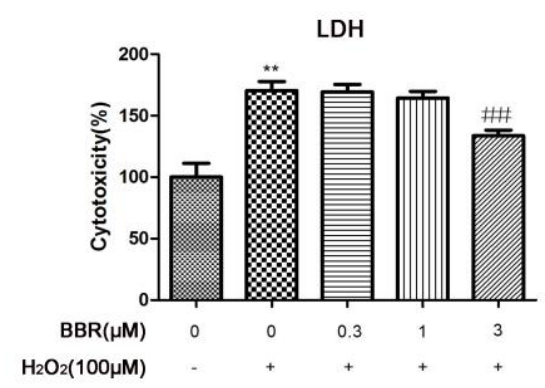

(D)

Figure 1. Protective effects of berberine (BBR) against $\mathrm{H}_{2} \mathrm{O}_{2}$-induced cytotoxicity in $\mathrm{D} 407$ cells. (A) The structure of BBR; (B) D407 cells were treated with BBR $(0.3$ to $30 \mu \mathrm{M})$ or $0.1 \%$ dimethyl sulfoxide (DMSO) (vehicle control) for $24 \mathrm{~h}$ and cell viability was measured using 3-(4,5-dimethylthiazol-2-yl)-2,5-diphenyl tetrazolium bromide (MTT) assay. Cells were pre-treated with BBR at indicated concentration or $0.1 \%$ DMSO (vehicle control) for $2 \mathrm{~h}$ and then incubated with or without $100 \mu \mathrm{M} \mathrm{H}_{2} \mathrm{O}_{2}$ for further $24 \mathrm{~h}$. Cell viability and the release of lactate dehydrogenase (LDH) were measured by MTT assay $(\mathrm{C})$ and LDH assay (D), respectively. ${ }^{*}$ indicates $p<0.05,{ }^{* *}$ indicates $<0.01,{ }^{* * *}$ indicates $p<0.001$ versus the control group; " indicates $p<0.05$, \#\# indicates $p<0.01$ versus the $\mathrm{H}_{2} \mathrm{O}_{2}$-treated group were considered significantly different.

\section{Results}

\subsection{BBR Reduced $\mathrm{H}_{2} \mathrm{O}_{2}$-Induced D407 Cell Death}

D407 cells were incubated with different concentrations of BBR for $24 \mathrm{~h}$, in order to evaluate the cytotoxicity of BBR, and cell viability was assessed using 3-(4,5-dimethylthiazol-2-yl)-2,5-diphenyl tetrazolium bromide (MTT) assay. As shown in Figure 1B, BBR with a concentration from 0.3 to $3 \mu \mathrm{M}$ did not cause any cytotoxicity in D407 cells compared to the control group. Therefore, these concentrations of BBR were chosen in further experiments. To investigate the protective effects of BBR on $\mathrm{H}_{2} \mathrm{O}_{2}$-induced D407 cell death, D407 cells were treated with BBR for $2 \mathrm{~h}$ before being exposed to $\mathrm{H}_{2} \mathrm{O}_{2}$ for $24 \mathrm{~h}$. The result from MTT assay showed that treatment of $100 \mu \mathrm{M}$ $\mathrm{H}_{2} \mathrm{O}_{2}$ resulted in a significant reduction of cell viability, whereas pre-treatment with 1 or $3 \mu \mathrm{M}$ BBR significantly attenuated $\mathrm{H}_{2} \mathrm{O}_{2}$-induced cell viability loss in a concentration-dependent manner (Figure 1C). The protective activity of BBR was also confirmed by the lactate dehydrogenase (LDH) assay as shown in Figure 1D, in which pre-treatment with $3 \mu \mathrm{M}$ BBR for $2 \mathrm{~h}$ significantly reduced $\mathrm{H}_{2} \mathrm{O}_{2}$-induced LDH leakage.

\subsection{BBR Attenuated $\mathrm{H}_{2} \mathrm{O}_{2}$-Induced Apoptosis in D407 Cells}

D407 cells pretreated with BBR were further exposed to $100 \mu \mathrm{M} \mathrm{H}_{2} \mathrm{O}_{2}$ for $24 \mathrm{~h}$, and stained with Hoechst 33342.The results showed that $100 \mu \mathrm{M} \mathrm{H}_{2} \mathrm{O}_{2}$ caused remarkable nuclei condensation in cells. However, these changes induced by $\mathrm{H}_{2} \mathrm{O}_{2}$ were not seen when the cells were pre-treated with $3 \mu \mathrm{M}$ BBR (Figure 2). BBR itself did not lead to nuclear morphological changes in D407 cells. 

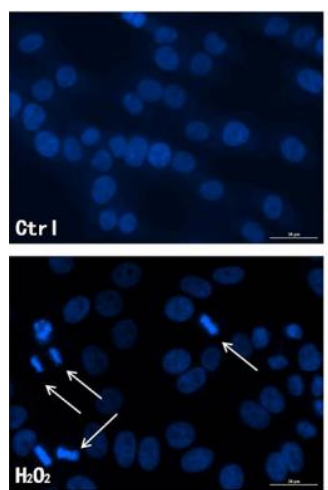

(A)

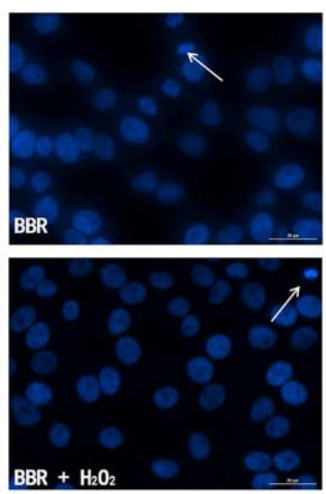

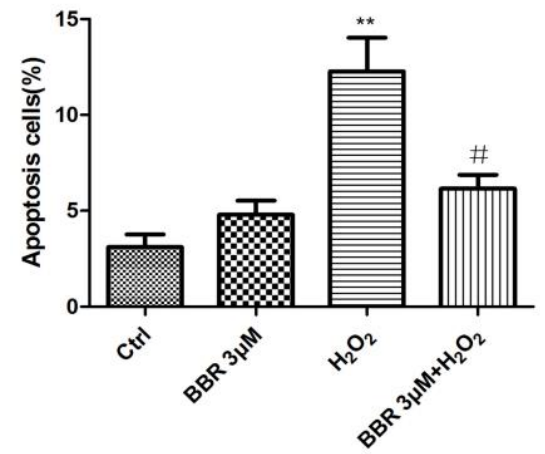

(B)

Figure 2. BBR attenuated $\mathrm{H}_{2} \mathrm{O}_{2}$-induced apoptosis in D407 cells. Apoptosis of D407 cells was detected by Hoechst 33342 staining and visualized by fluorescence microscopy. The number of apoptotic nuclei with condensed chromatin was counted from the photomicrographs and presented as a percentage of the total number of nuclei. ${ }^{* *}$ indicates $p<0.01$ versus the control group; ${ }^{\#}$ indicates $p<0.05$ versus the $\mathrm{H}_{2} \mathrm{O}_{2}$-treated group were considered significantly different.

\subsection{BBR Attenuated the Loss of Mitochondrial Membrane Potential and the Activation of Caspase 3/7 Induced} by $\mathrm{H}_{2} \mathrm{O}_{2}$

The dysregulated mitochondrial functioning causes the loss of mitochondrial membrane potential $(\Delta \psi \mathrm{m})$. To find out whether BBR could bring down the $\mathrm{H}_{2} \mathrm{O}_{2}$-induced $\Delta \psi \mathrm{m}$ loss, the mitochondrial membrane potential was determined by analyzing the red/green fluorescent intensity ratio of JC-1 staining in D407 cells. Exposure of D407 cells to $100 \mu \mathrm{M} \mathrm{H}_{2} \mathrm{O}_{2}$ resulted in an increase in green fluorescence intensity which indicated that mitochondrial membrane potential is dissipated (Figure 3A). Pre-treatment with BBR at $3 \mu \mathrm{M}$ concentration for $2 \mathrm{~h}$ significantly attenuated $\mathrm{H}_{2} \mathrm{O}_{2}$-induced $\Delta \psi \mathrm{m}$ loss. This indicated that $\mathrm{H}_{2} \mathrm{O}_{2}$ significantly decreased the mitochondrial membrane potential, an effect which was remarkably brought down when cells were pre-treated with BBR. To further verify the protective effects of BBR, Caspase 3/7 activity was determined. Caspase 3/7 is a main biomarker of the cell apoptosis. Treatment of D407 cells with $\mathrm{H}_{2} \mathrm{O}_{2}(100 \mu \mathrm{M})$ for $24 \mathrm{~h}$ resulted in an increase in caspase 3/7 activity by more than two-fold in comparison to the control group as shown in Figure 3B. In contrast, pre-treatment with BBR significantly brought down the caspase $3 / 7$ activation initiated by $\mathrm{H}_{2} \mathrm{O}_{2}$.
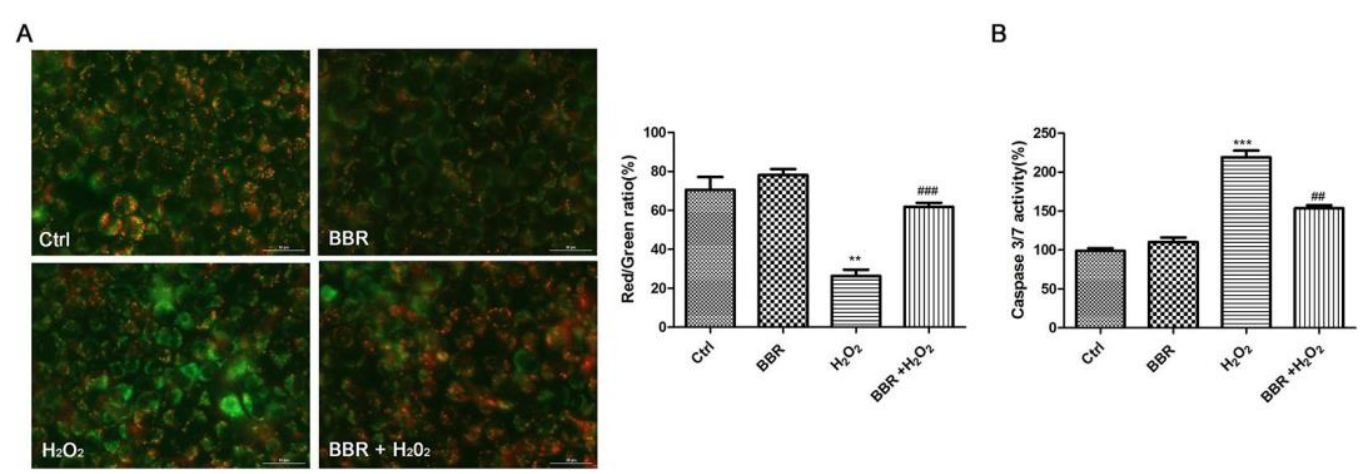

Figure 3. BBR attenuated $\mathrm{H}_{2} \mathrm{O}_{2}$-induced loss of mitochondrial membrane potential $(\Delta \psi \mathrm{m})$ and activation of caspase 3/7 in D407 cells. After pre-treatment with $3 \mu \mathrm{M}$ BBR or $0.1 \%$ DMSO (vehicle control) for $2 \mathrm{~h}$, D407 cells were incubated with or without $100 \mu \mathrm{M} \mathrm{H}_{2} \mathrm{O}_{2}$ for another $24 \mathrm{~h}$. (A) $\Delta \psi \mathrm{m}$ was determined by JC-1 assay; (B) Quantification of caspase 3/7 activity was determined by caspase $3 / 7$ activity assay. ${ }^{* *}$ indicate $p<0.01,{ }^{* * *}$ indicate $p<0.001$ versus the control group; ${ }^{\# \#}$ indicate $p<0.01$, \#\#\# indicate $p<0.001$ versus the $\mathrm{H}_{2} \mathrm{O}_{2}$-treated group were considered significantly different. 


\subsection{BBR Attenuated the $\mathrm{H}_{2} \mathrm{O}_{2}$-Induced ROS Production}

The cytotoxicity of $\mathrm{H}_{2} \mathrm{O}_{2}$ was mediated by increased levels of ROS in the D407 cell. Therefore, we used CellROX Deep Red Reagent staining to investigate the effects of BBR on the oxidation induced by $\mathrm{H}_{2} \mathrm{O}_{2}$. As shown in Figure 4, exposure of D407 cells to $100 \mu \mathrm{M} \mathrm{H}_{2} \mathrm{O}_{2}$ resulted in an increase of ROS level. However, pre-treatment of cells with BBR at $3 \mu \mathrm{M}$ inhibited the $\mathrm{H}_{2} \mathrm{O}_{2}$-induced increase of ROS level in D407 cells.
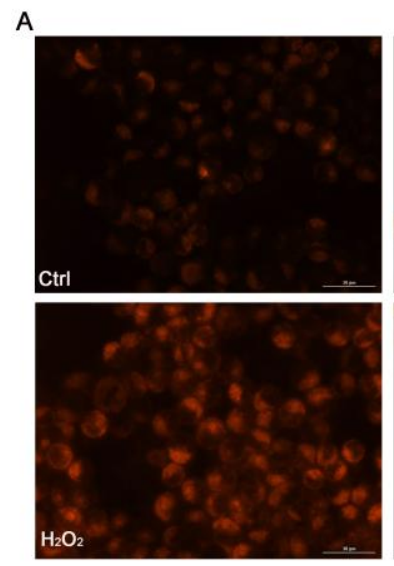

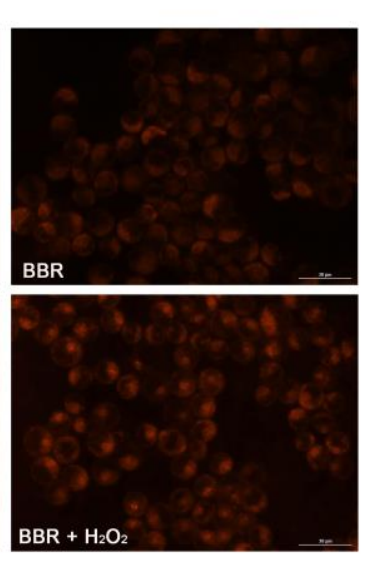

B

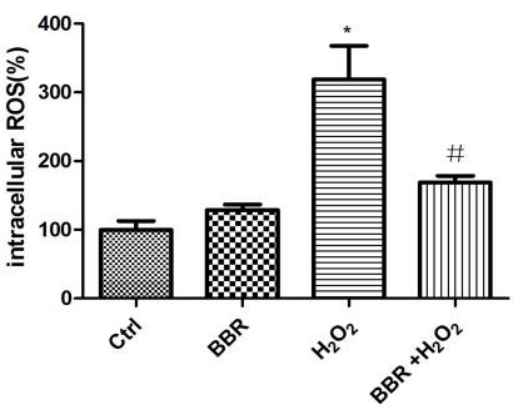

Figure 4. BBR attenuated the $\mathrm{H}_{2} \mathrm{O}_{2}$-induced reactive oxygen species (ROS) production. Exposure of D407 cells to $100 \mu \mathrm{M} \mathrm{H}_{2} \mathrm{O}_{2}$ resulted in an increase of ROS level. Pre-treatment of cells with BBR at $3 \mu \mathrm{M}$ inhibited the $\mathrm{H}_{2} \mathrm{O}_{2}$-induced increase of ROS level in D407 cells. After pre-treatment with $3 \mu \mathrm{M}$ BBR or $0.1 \%$ DMSO (vehicle control) for $2 \mathrm{~h}$, D407 cells were incubated with or without $100 \mu \mathrm{M} \mathrm{H}_{2} \mathrm{O}_{2}$ for another $24 \mathrm{~h}$. * indicates $p<0.05$ versus the control group were considered statistically different.

\# indicates $p<0.05$ versus the $\mathrm{H}_{2} \mathrm{O}_{2}$-treated group were considered statistically different.

\subsection{BBR Stimulated AMPK Phosphorylation in D407 Cells}

BBR has been shown to activate AMPK signaling in many cell types [31-34]. In order to find out whether AMPK signaling is regulated by BBR in D407 cells, the cells were treated with $3 \mu \mathrm{M}$ BBR for different time points or with different concentrations of BBR for $80 \mathrm{~min}$ as shown in Figure 5, and the phosphorylation level of AMPK was checked by Western blotting. As shown in Figure 5A,B, BBR time-dependently stimulated the phosphorylation of AMPK. The stimulation was seen at $10 \mathrm{~min}$, reached maximum at $80 \mathrm{~min}$ and decreased afterwards. Figure 5C,D showed the concentration-dependent stimulation of phosphorylation of AMPK by BBR. The lowest effective concentration of BBR found to stimulate AMPK phosphorylation was $0.3 \mu \mathrm{M}$ and the maximum effect was observed at $3 \mu \mathrm{M}$.

\subsection{The Protective Effect of BBR Was Mediated by AMPK Signaling}

To further confirm the involvement of AMPK signaling in the protective effects of BBR, AMPK specific inhibitor Compound $\mathrm{C}$ was introduced to the following experiment. As shown in Figure 6A, the result of MTT assay indicated that the protective effect of BBR was abolished by pre-incubation with Compound C, suggesting that AMPK signaling activation is essential in the protective effects of BBR. In line with this finding, Western blotting also showed that Compound $C$, at the concentration that blocked the protective effect of BBR, also blocked BBR-induced AMPK phosphorylation (Figure 6B). To further ascertain the mediated effect of AMPK, we used specific siRNA for AMPK to knock down the expression of AMPK in D407 cells. As expected, down regulation of AMPK (Figure 7A) notably reduced the protective effect of BBR in D407 cells (Figure 7B). 
A

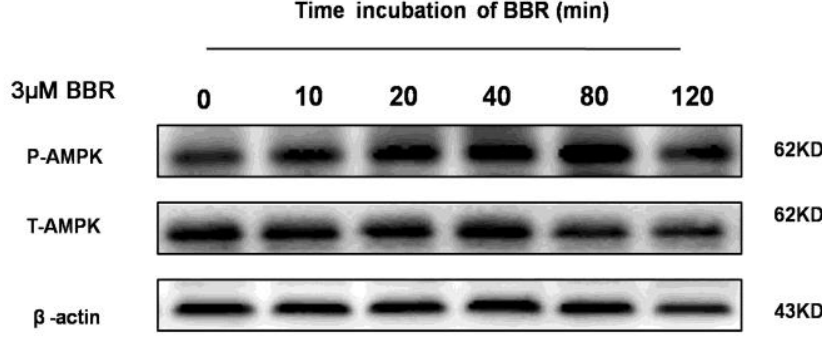

C

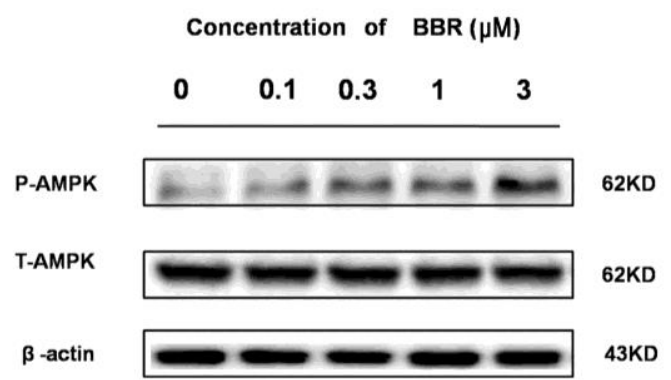

B

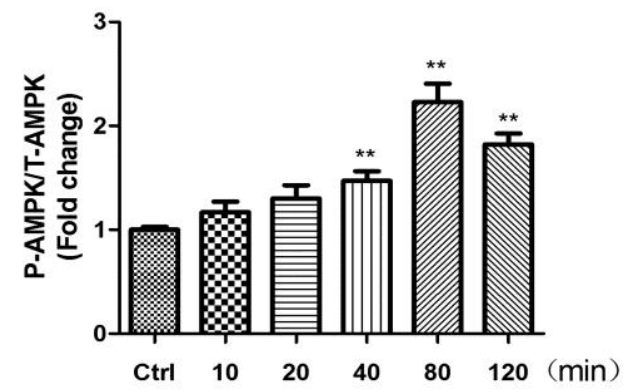

D

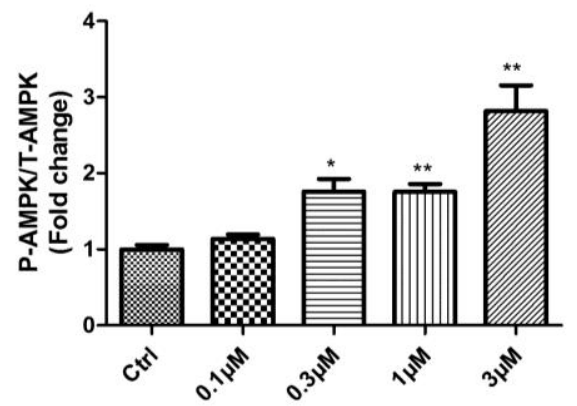

Figure 5. BBR stimulated AMPK phosphorylation in D407 cells. (A) D407 cells were treated with $3 \mu \mathrm{M}$ BBR for various time points as indicated in the Figure and the phosphorylation of AMPK (P-AMPK), total AMPK (T-AMPK), and $\beta$-actin were detected by Western blotting with specific antibodies; (B) Quantification of representative protein band from Western blotting. ${ }^{*} p<0.05$ versus the control group was considered significantly different; (C) D407 cells were treated with various concentrations of BBR for $80 \mathrm{~min}$ and the expression of phosphorylated AMPK (P-AMPK), total AMPK (T-AMPK), and $\beta$-actin were detected by Western blotting with specific antibodies (D). Quantification of representative protein band from Western blotting. ${ }^{*}$ indicate $p<0.05,{ }^{* *}$ indicate $p<0.01$ versus the control group was considered significantly different.

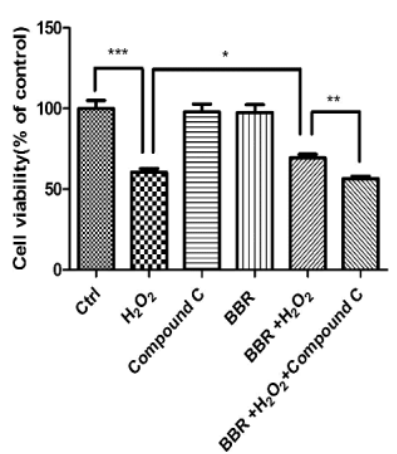

(A)

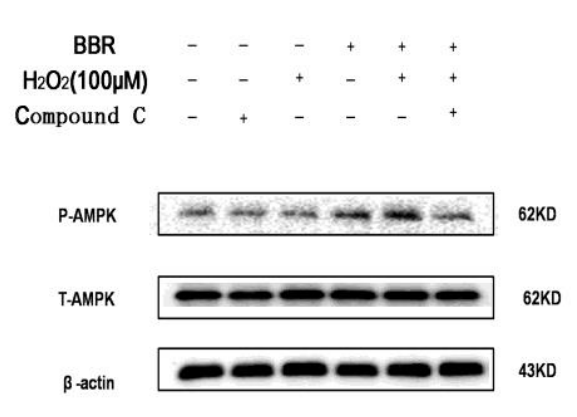

(B)

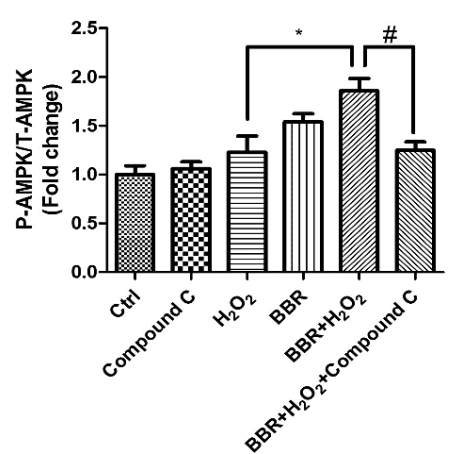

(C)

Figure 6. AMPK specific inhibitor Compound C blocked the protective effect of BBR in D407 cells. (A) D407 cells were pre-treated with $5 \mu \mathrm{M}$ Compound $\mathrm{C}$ for $30 \mathrm{~min}$ and $3 \mu \mathrm{M}$ BBR for $2 \mathrm{~h}$ and then incubated with or without $\mathrm{H}_{2} \mathrm{O}_{2}$ for a further $24 \mathrm{~h}$. Cell viability was measured by MTT assay. ${ }^{*}$ indicates $p<0.05$. ${ }^{* *}$ indicates $p<0.01,{ }^{* * *}$ indicates $p<0.001$ was considered significantly different; (B) D407 cells were pre-treated with $5 \mu \mathrm{M}$ Compound C for 30 min and $3 \mu \mathrm{MBBR}$ for $80 \mathrm{~min}$ and then incubated with or without $\mathrm{H}_{2} \mathrm{O}_{2}$ for a further $2 \mathrm{~h}$. The expression of phosphorylated AMPK, total AMPK, and $\beta$-actin were detected by Western blotting with specific antibodies; (C) Quantification of representative protein band from Western blotting. * indicates $p<0.05$ versus the $\mathrm{H}_{2} \mathrm{O}_{2}$ group was considered significantly different. ${ }^{\#}$ indicates $p<0.05$ versus the $\mathrm{BBR}+\mathrm{H}_{2} \mathrm{O}_{2}$-treated group was considered significantly different. 
A

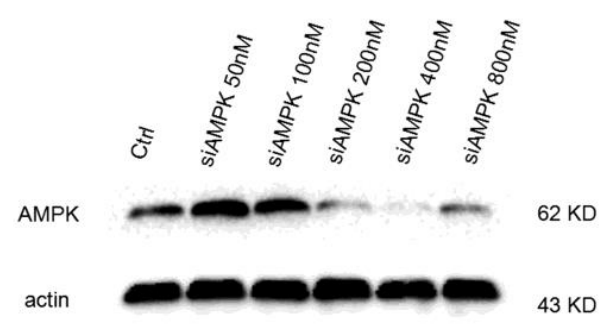

B

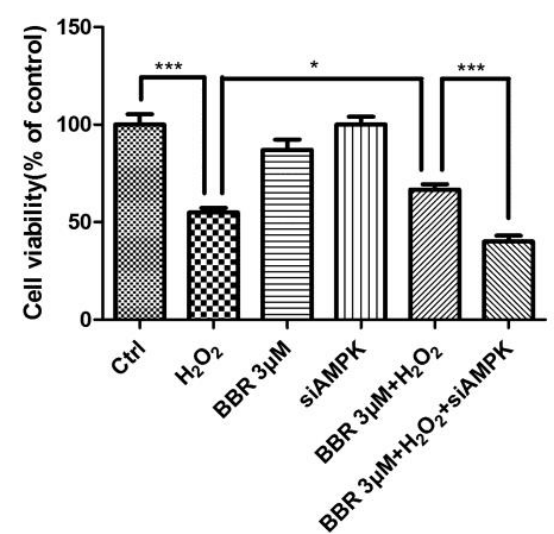

Figure 7. Knocking down the expression of AMPK by siRNA blocked the protective effect of BBR in D407 cells. (A) Cells were transfected with different concentrations of siAMPK for $48 \mathrm{~h}$ and the expression of AMPK or $\beta$-actin was detected by Western blotting; (B) Cells were transfected with $400 \mathrm{nM}$ siAMPK, transfected cells were seeded in 96-well, $24 \mathrm{~h}$ later treated with $3 \mu \mathrm{M}$ BBR or $0.1 \%$ DMSO (vehicle control) for $2 \mathrm{~h}$ and then incubated with or without $100 \mu \mathrm{M} \mathrm{H}_{2} \mathrm{O}_{2}$ for another $24 \mathrm{~h}$. Cell viability were measured by MTT assay. ${ }^{*}$ indicates $p<0.05,{ }^{* * *}$ indicates $p<0.001$ was considered significantly different.

\subsection{BBR Protected Primary Cultured Human RPE Cells against $\mathrm{H}_{2} \mathrm{O}_{2}$ Induced Injury via the AMPK Pathway}

To verify whether the protective effect of BBR is limited to D407 cell line, we also characterized its protective effects on primary cultured human retinal pigment epithelial cells (hRPE cells). The effect of BBR on the primary cultured hRPE cells exposed to $\mathrm{H}_{2} \mathrm{O}_{2}$ injury is presented in Figure 8. BBR successfully conferred protection of primary cultured hRPE cells against $\mathrm{H}_{2} \mathrm{O}_{2}$ insult in a concentration-dependent manner. Moreover, the protective effect of BBR is also inhibited by Compound C in these cells. These results are in accordance with the results from D407 cells, which further confirmed that BBR is able to protect hRPE cells from oxidative stress via the AMPK pathway.

A

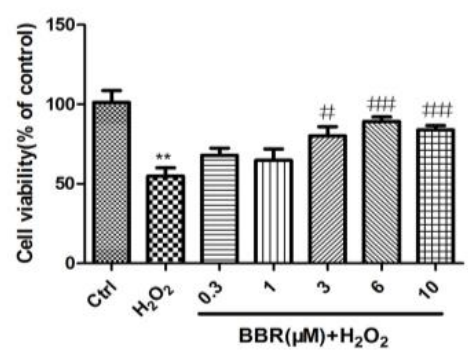

B

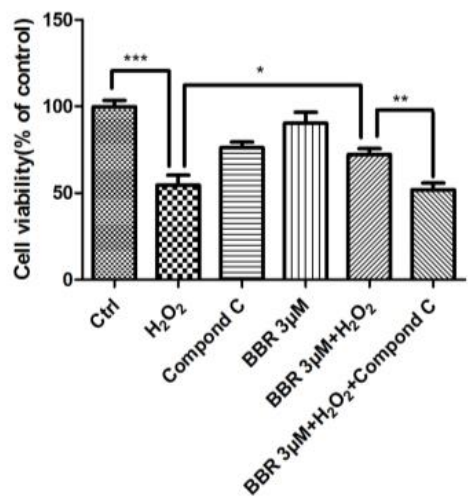

Figure 8. BBR protected primary cultured human RPE cells against $\mathrm{H}_{2} \mathrm{O}_{2}$ induced injury via the AMPK pathway. (A) Primary cultured hRPE cells were pre-treated with different concentrations of BBR for $2 \mathrm{~h}$, then incubated with or without $\mathrm{H}_{2} \mathrm{O}_{2}$ for a further $24 \mathrm{~h}$. Cell viability was measured by MTT assay. ${ }^{* *}$ indicates $p<0.01$ versus the control group was considered significantly different, " indicates $p<0.05$, ${ }^{\#}$ indicates $p<0.01$ versus $\mathrm{H}_{2} \mathrm{O}_{2}$ group was considered significantly different; (B) Primary cultured hRPE cells were pre-treated with $5 \mu \mathrm{M}$ Compound $\mathrm{C}$ for $30 \mathrm{~min}$ and $3 \mu \mathrm{MBBR}$ for $2 \mathrm{~h}$ and then incubated with or without $\mathrm{H}_{2} \mathrm{O}_{2}$ for further $24 \mathrm{~h}$, and cell viability was measured using the MTT assay. ${ }^{*}$ indicates $p<0.05,{ }^{* *}$ indicates $p<0.01,{ }^{* * *}$ indicates $p<0.001$ was considered significantly different. 


\section{Discussion}

Clinical and experimental data supports that chronic oxidative stress is a primary contributing factor to numerous retinal degenerative diseases, such as AMD [35]. The clinical eye samples obtained from dead patients have shown pervasive free radical impairment in the DNA, lipids, proteins and mitochondria of RPE cells [36]. Also, several mouse models of chronic oxidative stress have been shown to develop many of the pathological signs of AMD [37,38]. More importantly, data from animal and clinical studies suggested that the use of antioxidant drugs could be a potential strategy for delaying the progression of AMD and vision loss [39-41]. BBR, a well-known constituent of the Chinese herb Huanglian has displayed antioxidant properties in a variety of cells [27,42-45]. Recently, it was reported that systemic BBR was able to protect against light-induced retinal degeneration associated with diminished oxidative stress in the retina [46]. In the present study, we found that $\mathrm{H}_{2} \mathrm{O}_{2}(100 \mu \mathrm{M})$ exposure lead to the collapse of the $\Delta \psi \mathrm{m}$ and increase of ROS in RPE cells, while pre-treatment of BBR significantly reduced these abnormal changes in D407 RPE cells. During treatment with $\mathrm{H}_{2} \mathrm{O}_{2}$, cells are exposed to high concentrations of ROS, which consequently disrupts the balance between oxidants and antioxidants, resulting in apoptosis and/or necrosis of cells. In the current study, the frequent type of cell death observed in $\mathrm{H}_{2} \mathrm{O}_{2}$-treated RPE cells was apoptosis, which was significantly reduced by BBR. Furthermore, pretreatment with BBR prior to incubation with $\mathrm{H}_{2} \mathrm{O}_{2}$ significantlyattenuated the alteration caused by $\mathrm{H}_{2} \mathrm{O}_{2}$ exposure, such as the loss of cell viability, the elevation of LDH release and nuclear morphological changes, suggesting that anti-oxidant activity of BBR contributes to its protective effects. The concentration range of BBR used in our experiments had no toxicity in D407 cells which indicated that BBR is a safe protectant.

Mitochondrial dysfunctions have been implicated in the pathophysiology of several age-related diseases including AMD [47]. Mitochondrial apoptotic pathway activation resulting from mitochondrial deficiency plays a crucial role in the pathogenesis of retinal diseases [48]. It has been reported that compounds which improve mitochondrial functions may show beneficial effects in preventing AMD $[49,50]$. BBR has been shown to exert protective effects in disease models of various diseases such as hepatic disease [51], obesity [52], and myocardial ischemia [53], etc., by restoring the dysregulated mitochondrial function. And BBR has been showed to attenuate ischemia/reperfusion injury by inhibiting endoplasmic reticulum and mitochondrial stress pathways [54]. Moreover, BBR is believed to interplay with various enzymes, receptors and iron channel that are involved in mitochondria functions [23].

Consistent with above report, our results also revealed that BBR reversed $\mathrm{H}_{2} \mathrm{O}_{2}$-induced ROS accumulation, $\triangle \psi \mathrm{m}$ loss and suppress the activation of caspase $3 / 7$ in D407 cells caused by $\mathrm{H}_{2} \mathrm{O}_{2}$. These findings indicated mitochondria injury plays an important role in the protective effect of BBR. Thus our findings for the first time showed that BBR could increase mitochondrial membrane potential in D407 cells treated with $\mathrm{H}_{2} \mathrm{O}_{2}$. As mitochondria are dynamic organelles with the ability to fuse (fusion) and divide (fission), mitochondria-related parameters, such as mitochondrial biogenesis, ATP production, expression of complex I-IV proteins and the level of MnSOD are pivotal indicators showing the biological functions of mitochondria. All these potential parameters are deserved to be investigated in the future.

BBR is a very well-known activator of AMPK which also triggers beneficial metabolic activities in diabetic as well as insulin-resistant states [55]. Recent reports have suggested the involvement of AMPK in mediating cell survival or apoptosis under stress condition [56-58]. It is reported that short term treatment with BBR results in ATP depletion, which further leads to AMPK activation and mitochondrial fragmentation $[59,60]$. Further studies suggested that BBR was able to reduce mitochondrial dysfunction induced by high fat diet and hyperglycemia in skeletal muscle via AMPK activation $[52,59]$. More interestingly, AMPK signaling axis was also reported to play a crucial role in RPE cell apoptosis [61]. In present study, we observed that BBR treatment lead to a significant increase in AMPK phosphorylationin D407 cells. In addition, BBR triggered protective effects against cell viability lose and cell apoptosis was attenuated by specific pharmacological inhibitors of AMPK 
kinase (Compound C) or specific siRNA for AMPK. Therefore, these results provided mechanistic evidences to support the notion that BBR-regulated protective effects against $\mathrm{H}_{2} \mathrm{O}_{2}$-induced oxidative stress in D407 cells are implemented via AMPK activation. Consequently, this protective effect of BBR was reproduced and confirmed in primary cultured human RPE cells.

In summary, our findings demonstrated that BBR is able to significantly attenuate $\mathrm{H}_{2} \mathrm{O}_{2}$-induced oxidative injury in D407 cells through modulating $\Delta \psi \mathrm{m}$ and caspase $3 / 7$ dependent pathway, inhibiting the generation of intracellular ROS, and activating AMPK signaling. Therefore, the protective activity of BBR to attenuate $\mathrm{H}_{2} \mathrm{O}_{2}$-mediated intrinsic mitochondrial apoptotic pathway are at least partially, mediated via the activation of AMPK signaling pathway (Figure 9). Our results offer support for the potential application of BBR in preventing or delaying oxidative stress-induced retinal pigment epithelial cell death in the process of dry AMD.

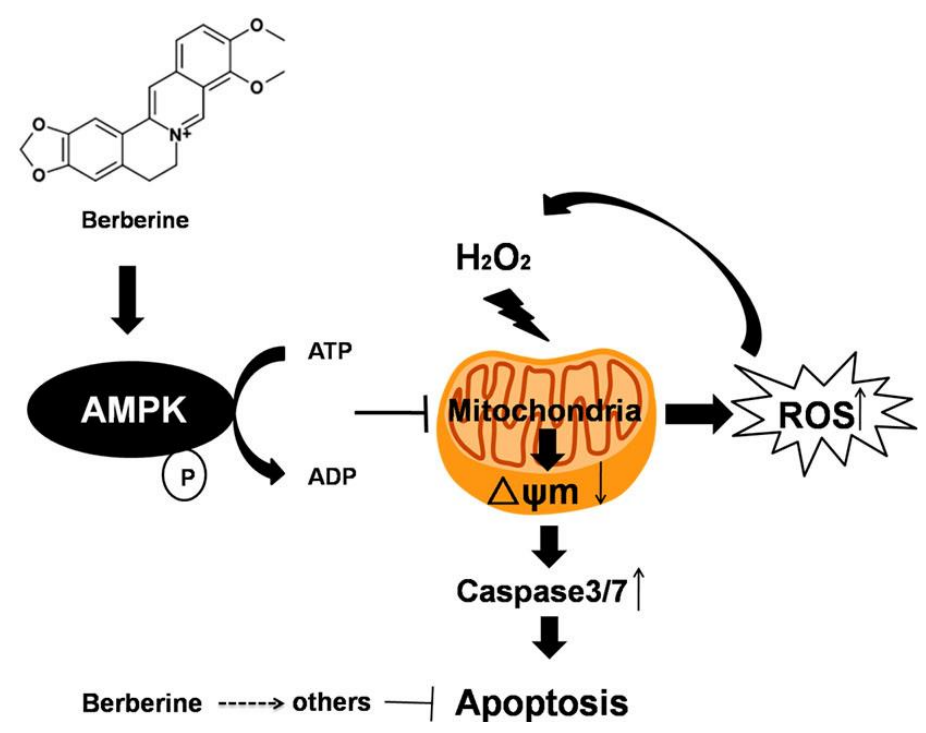

Figure 9. The possible mechanism of Berberine.

\section{Materials and Methods}

\subsection{Materials}

Human retinal pigment epithelial cell line D407 was obtained from cell bank, Sun Yat-sen University (Guangzhou, China); poly-L-lysine and bovine serum albumin were purchased from Sigma (St. Louis, MO, USA); dimethyl sulfoxide (DMSO). penicillin-streptomycin (PS); trypsin; Fetal bovine serum (FBS) and DMEM were purchased from Invitrogen (Carlsbad, CA, USA); methyl thiazolyl tetrazolium (MTT), JC-1, and Hoechst 33342 were purchased from Molecular Probes (Eugene, OR, USA). Caspase-Glo ${ }^{\circledR} 3 / 7$ Assay kit was purchased from Invitrogen, USA. CytoTox-ONETM Homogeneous Membrane Integrity Assay (Promega, Madison, WI, USA) kit; CellROX Deep Red Reagent was purchased from Thermo Fisher Scientific, Waltham, MA, USA. Western blotting and protein quantification materials were purchased from Bio-Rad (Hercules, CA, USA). Super Signal West Pico chemiluminescent substrate was purchased from Thermo Scientific (Rockford, IL, USA). Anti- $\beta$-actin, phospho-AMPK and total AMPK antibodies were purchased from Cell Signaling Technology (Woburn, MA, USA). AMPK inhibitor (Compound C) was purchased from Selleckchem. siAMPK was purchased from Molecular Informatrix Laboratory.

\subsection{Cell Culture}

Cell line D407 was maintained and grown in DMEM culture medium with 10\% FBS (heat-treated at $56^{\circ} \mathrm{C}$ for $\left.30 \mathrm{~min}\right)$. Streptomycin $(100 \mu \mathrm{g} / \mathrm{L})$ and penicillin $(100 \mathrm{U} / \mathrm{mL})$ were added into the medium. 
Cells were incubated at $37{ }^{\circ} \mathrm{C}$ with $5 \% \mathrm{CO}_{2}$-humidified atmosphere. The medium was replaced every 3 days, and cells were sub-cultured by $0.25 \%$ trypsin treatment twice a week. The cells of passages 3 to 8 were used in further experiments. Primary Cultured Human retinal pigment epithelial (hRPE) cells were obtained from the State Key Laboratory of Ophthalmology, Zhongshan Ophthalmic Center and were approved by the Ethics Committee of Zhongshan Ophthalmic Center (2018KYPJ082, 15 May 2018). The cells were grown in DMEM/F12 culture medium augmented with $10 \%$ FBS and $1 \%$ penicillin/streptomycin in a humidified incubator at $37^{\circ} \mathrm{C}$ and $5 \% \mathrm{CO}_{2}$.

\subsection{MTT Assay}

Cell viability was checked by 3-(4,5-dimethylthiazol-2-yl)-2,5-diphenyl tetrazolium bromide (MTT) assay. In brief, D407 cells were grown in 96-well plates at a density of $5 \times 10^{4}$ cells $/ \mathrm{mL}$. After serum deprivation, the D407 cells were exposed to reagents for $24 \mathrm{~h}$. Then, MTT $(0.5 \mathrm{mg} / \mathrm{mL})$ was added into the plate and incubated for $3 \mathrm{~h}$ at $37^{\circ} \mathrm{C}$. The medium was aspirated from each well and DMSO $(100 \mu \mathrm{L})$ was added to dissolve the formazan crystals. The data were quantified spectrophotometrically at wavelength of $490 \mathrm{~nm}$.

\subsection{LDH Assay}

Through measuring the activity of lactate dehydrogenase (LDH) released into the incubation medium when cellular membranes are damaged, we can know the Cell cytotoxicity. D407 cells were seeded into 96-well plates $\left(5 \times 10^{4}\right.$ cells $\left./ \mathrm{mL}\right)$. The activity of LDH released in the medium was measured following the manufacturer's instructions. Infinite M200 PRO Multimode Microplate reader was used to measure the fluorescent intensity at an excitation wavelength of $560 \mathrm{~nm}$ and emission wavelength of $590 \mathrm{~nm}$.

\subsection{Hoechst 33342 Staining}

Apoptosis of cells was assessed by staining with the DNA binding dye Hoechst 33342. D407 cells were grown into 96-well plates $\left(1 \times 10^{4}\right.$ cells/well). After suitable treatment, the cells were thoroughly washed with PBS, fixed with $4 \%$ formaldehyde in PBS for $10 \mathrm{~min}$. Cells were then incubated with $10 \mu \mathrm{g} / \mathrm{mL}$ of Hoechst 33342 for $20 \mathrm{~min}$ to stain the nuclei at room temperature. The cells were washed again with PBS before the nuclei were visualized using EVOS FL Imaging System (Thermo Fisher Scientific, Waltham, MA, USA).

\subsection{Measurement of Cellular Oxidation (ROS)}

The extent of oxidation was evaluated using CellROX Deep Red Reagent. For $1 \mathrm{~h}$ the cells were incubated with CellROX Deep Red Reagent $(5 \mu \mathrm{M})$ in DMEM in dark followed by rinsing twice with PBS and finally the fluorescence was recorded using fluorescent microscope at the wavelength of $640 \mathrm{~nm}$ and $665 \mathrm{~nm}$ for excitation and emission respectively. Semi-quantification of ROS level was assessed by using Image J software. All values of \%ROS level were normalized to the control group.

\subsection{Measurement of Mitochondrial Membrane Potential $(\Delta \Psi m)$}

JC-1 dye was used to monitor $\Delta \psi \mathrm{m}$. In brief, D407 cells were grown into 96-well plates $\left(2 \times 10^{4}\right.$ cells/well). After treatment, the cells were incubated with JC-1 $(10 \mu \mathrm{g} / \mathrm{mL}$ in medium $)$ at $37^{\circ} \mathrm{C}$ for $15 \mathrm{~min}$ and then washed twice with PBS. For signal quantification, the intensity of red fluorescence (excitation $560 \mathrm{~nm}$, emission $595 \mathrm{~nm}$ ) and green fluorescence (excitation $485 \mathrm{~nm}$, emission $535 \mathrm{~nm}$ ) were determined using a Multiskan Ascent Revelation Plate Reader. The ratio of JC-1 red/green fluorescence intensity was calculated for semi-quantitative assessment of mitochondrial polarization states and the value was normalized to the control group. 


\subsection{Caspase 3/7 Activity Assay}

The activity of caspase $3 / 7$ was measured using Caspase-Glo ${ }^{\circledR} 3 / 7$ Assay kit according to the manufacturer's protocol. Briefly, D407 cells were lysed in lysis buffer, then centrifuged at $12,500 \times g$ for $5 \mathrm{~min}$. $15 \mu \mathrm{L}$ of cell lysate was incubated with $50 \mu \mathrm{L}$ of $2 \times$ substrate working solution at room temperature for $30 \mathrm{~min}$ in 96-well plates. The fluorescence intensity was determined by Infinite M200 PRO Multimode Microplate reader at an excitation wavelength of $490 \mathrm{~nm}$ and emission wavelength of $520 \mathrm{~nm}$. The fluorescence intensity of each sample was normalized to the protein concentration of sample. All values of \% caspase 3/7 activities were normalized to the control group.

\subsection{Western Blotting}

Western blotting was performed as previously described [22]. Briefly, the harvested cells from different experimental conditions were rinsed once with ice-cold PBS and lysed in RIPA buffer. Protein concentration was determined by a BCA protein assay kit according to the manufacturer's instructions. Aliquots of protein samples $(30 \mu \mathrm{g})$ were boiled for $10 \mathrm{~min}$ at $95^{\circ} \mathrm{C}$ and electrophoresed on SDS-PAGE $(10 \%(w / v)$ polyacrylamide gel) and then transferred to a nitrocellulose (NC) membrane (Millipore, Billerica, MA, USA). Subsequently, the membranes were blocked with $3 \%(w / v)$ BSA in TBST (TBS containing $0.1 \%$ Tween-20) for $1 \mathrm{~h}$ at room temperature. The blots were incubated overnight at $4{ }^{\circ} \mathrm{C}$ with primary antibodies. After washing with TBST for $30 \mathrm{~min}$ at room temperature, the membranes were further incubated with horseradish peroxidase-conjugated secondary antibodies for $1 \mathrm{~h}$ at room temperature. Blots were visualized using ECL kit according to the manufacturer's instructions. The intensity of the bands was semi-quantified using Image J software.

\subsection{AMPK Silencing by Transfection siAMPK}

Before silencing, cells were cultured at $100 \%$ confluency. The day before the experiment, the cells were harvested by trypsinization, resuspended in complete medium at the concentration of $1 \times 10^{5}$ cells $/ \mathrm{mL}$, and incubated at $37^{\circ} \mathrm{C}$, while the transfection complex was being prepared. Gene silencing of AMPK was performed by specifically synthesized siRNA. On the day of the experiment, transfection siRNA or scrambled sequence as control was incubated with Lipo2000 and opti-MEM following manufacturer's instructions. After 15 min incubation at room temperature, the obtained complexes were added drop-wise onto the cells sub-cultured in replaced culture medium. The cells were maintained in a $37^{\circ} \mathrm{C}$ incubator for $6 \mathrm{~h}$ and the medium was replaced with complete medium until analysis. After $48 \mathrm{~h}$ from transfection, the cells were collected for protein expression analyses of AMPK. For the MTT assay, cells were seeded into 96-well plates after $24 \mathrm{~h}$ from transfection, and MTT assay was performed using standard protocol. The data were quantified by GraphPad Prism 5.0 statistical software.

\subsection{Statistical Analysis}

Statistical analysis was performed using the GraphPad Prism 5.0 statistical software. All experiments were performed in triplicates. Data was expressed as means \pm standard deviation (SD). Statistical analysis was carried out using one-way ANOVA followed by Tukey's multiple comparison, with $p<0.05$ considered statistically significant.

Author Contributions: W.Z. conceived and designed the experiments. S.L., U.G., C.-M.C., J.F., Z.Z., and H.W. performed the experiments and analyzed the data. S.L., U.G., C.-M.C. and W.Z. wrote the manuscript, S.L. performed the experiments and provided the primary cultured human RPE cells, and W.Z. finally approved the manuscript. All authors read and approved the manuscript.

Acknowledgments: This research was supported by National Natural Science Foundation of China (No. 31771128, No. 81301099 and No. 31371088), MYRG2016-00052-FHS and MYRG2018-00134-FHS from University of Macau, and the Science and Technology Development Fund (FDCT) of Macao (FDCT 021/2015/A1 and 016/2016/A1).

Conflicts of Interest: The authors declare that they have no conflicts of interest. 


\section{References}

1. Handa, J.T.; Cano, M.; Wang, L.; Datta, S.; Liu, T. Lipids, oxidized lipids, oxidation-specific epitopes, and age-related macular degeneration. Biochim. Biophys. Acta 2017, 1862, 430-440. [CrossRef] [PubMed]

2. Lim, L.S.; Mitchell, P.; Seddon, J.M.; Holz, F.G.; Wong, T.Y. Age-related macular degeneration. Lancet 2012, 379, 1728-1738. [CrossRef]

3. Jager, R.D.; Mieler, W.F.; Miller, J.W. Age-related macular degeneration. N. Engl. J. Med. 2008, 358, $2606-2617$. [CrossRef] [PubMed]

4. Kaarniranta, K.; Kauppinen, A.; Blasiak, J.; Salminen, A. Autophagy regulating kinases as potential therapeutic targets for age-related macular degeneration. Future Med. Chem. 2012, 4, 2153-2161. [CrossRef] [PubMed]

5. Nowak, J.Z. Age-related macular degeneration (AMD): Pathogenesis and therapy. Pharmacol. Rep. 2006, 58, 353-363. [PubMed]

6. Chappelow, A.V.; Kaiser, P.K. Neovascular age-related macular degeneration: Potential therapies. Drugs 2008, 68, 1029-1036. [CrossRef] [PubMed]

7. Damico, F.M.; Gasparin, F.; Scolari, M.R.; Pedral, L.S.; Takahashi, B.S. New approaches and potential treatments for dry age-related macular degeneration. Arq. Bras. Oftalmol. 2012, 75, 71-76. [CrossRef] [PubMed]

8. Weismann, D.; Hartvigsen, K.; Lauer, N.; Bennett, K.L.; Scholl, H.P.; Issa, P.C.; Cano, M.; Brandstätter, H.; Tsimikas, S.; Skerka, C. Complement factor $\mathrm{h}$ binds malondialdehyde epitopes and protects from oxidative stress. Nature 2011, 478, 76-81. [CrossRef] [PubMed]

9. Grunwald, J.E.; Hariprasad, S.M.; DuPont, J.; Maguire, M.G.; Fine, S.L.; Brucker, A.J.; Maguire, A.M.; Ho, A.C. Foveolar choroidal blood flow in age-related macular degeneration. Investig. Ophthalmol. Vis. Sci. 1998, 39, 385-390.

10. Strauss, O. The retinal pigment epithelium in visual function. Physiol. Rev. 2005, 85, 845-881. [CrossRef] [PubMed]

11. Kozlowski, M.R. Rpe cell senescence: A key contributor to age-related macular degeneration. Med. Hypotheses 2012, 78, 505-510. [CrossRef] [PubMed]

12. Ida, H.; Ishibashi, K.; Reiser, K.; Hjelmeland, L.M.; Handa, J.T. Ultrastructural aging of the rpe-bruch's membrane-choriocapillaris complex in the d-galactose-treated mouse. Investig. Ophthalmol. Vis. Sci. 2004, 45, 2348-2354. [CrossRef]

13. Curcio, C.A.; Saunders, P.L.; Younger, P.W.; Malek, G. Peripapillary chorioretinal atrophy: Bruch's membrane changes and photoreceptor loss. Ophthalmology 2000, 107, 334-343. [CrossRef]

14. Anderson, R.E.; Rapp, L.M.; Wiegand, R.D. Lipid peroxidation and retinal degeneration. Curr. Eye Res. 1984, 3, 223-227. [CrossRef] [PubMed]

15. Catala, A. An overview of lipid peroxidation with emphasis in outer segments of photoreceptors and the chemiluminescence assay. Int. J. Biochem. Cell Biol. 2006, 38, 1482-1495. [CrossRef] [PubMed]

16. Lu, L.; Hackett, S.F.; Mincey, A.; Lai, H.; Campochiaro, P.A. Effects of different types of oxidative stress in rpe cells. J. Cell. Physiol. 2006, 206, 119-125. [CrossRef] [PubMed]

17. Kim, M.H.; Chung, J.; Yang, J.W.; Chung, S.M.; Kwag, N.H.; Yoo, J.S. Hydrogen peroxide-induced cell death in a human retinal pigment epithelial cell line, arpe-19. Korean J. Ophthalmol. 2003, 17, 19-28. [CrossRef] [PubMed]

18. Organisciak, D.T.; Vaughan, D.K. Retinal light damage: Mechanisms and protection. Prog. Retin. Eye Res. 2010, 29, 113-134. [CrossRef] [PubMed]

19. Mitra, R.N.; Merwin, M.J.; Han, Z.; Conley, S.M.; Al-Ubaidi, M.R.; Naash, M.I. Yttrium oxide nanoparticles prevent photoreceptor death in a light-damage model of retinal degeneration. Free Radic. Biol. Med. 2014, 75, 140-148. [CrossRef] [PubMed]

20. O'Driscoll, C.; Doonan, F.; Sanvicens, N.; Messeguer, A.; Cotter, T.G. A novel free radical scavenger rescues retinal cells in vivo. Exp. Eye Res. 2011, 93, 65-74. [CrossRef] [PubMed]

21. Age-Related Eye Disease Study Research Group. A randomized, placebo-controlled, clinical trial of high-dose supplementation with vitamins $\mathrm{c}$ and e, beta carotene, and zinc for age-related macular degeneration and vision loss: Areds report no. 8. Arch. Ophthalmol. 2001, 119, 1417-1436. 
22. Chong, C.M.; Zheng, W. Artemisinin protects human retinal pigment epithelial cells from hydrogen peroxide-induced oxidative damage through activation of erk/creb signaling. Redox Biol. 2016, 9, 50-56. [CrossRef] [PubMed]

23. Yao, J.; Kong, W.; Jiang, J. Learning from berberine: Treating chronic diseases through multiple targets. Sci. China Life Sci. 2015, 58, 854-859. [CrossRef] [PubMed]

24. Tong, N.; Zhang, J.; Chen, Y.; Li, Z.; Luo, Y.; Zuo, H.; Zhao, X. Berberine sensitizes mutliple human cancer cells to the anticancer effects of doxorubicin in vitro. Oncol. Lett. 2012, 3, 1263-1267. [CrossRef] [PubMed]

25. Cicero, A.F.; Baggioni, A. Berberine and its role in chronic disease. Adv. Exp. Med. Biol. 2016, 928, $27-45$. [PubMed]

26. Lau, C.W.; Yao, X.Q.; Chen, Z.Y.; Ko, W.H.; Huang, Y. Cardiovascular actions of berberine. Cardiovasc. Drug Rev. 2001, 19, 234-244. [CrossRef] [PubMed]

27. Hsu, Y.Y.; Chen, C.S.; Wu, S.N.; Jong, Y.J.; Lo, Y.C. Berberine activates Nrf2 nuclear translocation and protects against oxidative damage via a phosphatidylinositol 3-kinase/Akt-dependent mechanism in NSC34 motor neuron-like cells. Eur. J. Pharm. Sci. 2012, 46, 415-425. [CrossRef] [PubMed]

28. Wang, Q.; Qi, J.; Hu, R.; Chen, Y.; Kijlstra, A.; Yang, P. Effect of berberine on proinflammatory cytokine production by arpe-19 cells following stimulation with tumor necrosis factor- $\alpha$. Investig. Ophthalmol. Vis. Sci. 2012, 53, 2395-2402. [CrossRef] [PubMed]

29. Wei, S.; Zhang, M.; Yu, Y.; Lan, X.; Yao, F.; Yan, X.; Chen, L.; Hatch, G.M. Berberine attenuates development of the hepatic gluconeogenesis and lipid metabolism disorder in type 2 diabetic mice and in palmitate-incubated hepg2 cells through suppression of the hnf-4alpha mir122 pathway. PLoS ONE 2016, 11, e0152097. [CrossRef] [PubMed]

30. Chang, W.; Chen, L.; Hatch, G.M. Berberine treatment attenuates the palmitate-mediated inhibition of glucose uptake and consumption through increased 1,2,3-triacyl-sn-glycerol synthesis and accumulation in h9c2 cardiomyocytes. Biochim. Biophys. Acta 2016, 1861, 352-362. [CrossRef] [PubMed]

31. Wang, J.; Qi, Q.; Feng, Z.; Zhang, X.; Huang, B.; Chen, A.; Prestegarden, L.; Li, X.; Wang, J. Berberine induces autophagy in glioblastoma by targeting the ampk/mtor/ulk1-pathway. Oncotarget 2016, 7, 66944-66958. [CrossRef] [PubMed]

32. Fu, D.; Yu, J.Y.; Connell, A.R.; Yang, S.; Hookham, M.B.; McLeese, R.; Lyons, T.J. Beneficial effects of berberine on oxidized ldl-induced cytotoxicity to human retinal muller cells. Investig. Ophthalmol. Vis. Sci. 2016, 57, 3369-3379. [CrossRef] [PubMed]

33. Jeong, H.W.; Hsu, K.C.; Lee, J.-W.; Ham, M.; Huh, J.Y.; Shin, H.J.; Kim, W.S.; Kim, J.B. Berberine suppresses proinflammatory responses through ampk activation in macrophages. Am. J. Physiol. Endocrinol. Metab. 2009, 296, E955-E964. [CrossRef] [PubMed]

34. Cheng, Z.; Pang, T.; Gu, M.; Gao, A.-H.; Xie, C.-M.; Li, J.-Y.; Nan, F.-J.; Li, J. Berberine-stimulated glucose uptake in 16 myotubes involves both ampk and p38 mapk. Biochim. Biophys. Acta 2006, 1760, 1682-1689. [CrossRef] [PubMed]

35. Plafker, S.M.; O’Mealey, G.B.; Szweda, L.I. Mechanisms for countering oxidative stress and damage in retinal pigment epithelium. Int. Rev. Cell Mol. Biol. 2012, 298, 135-177. [PubMed]

36. Shen, J.; Dong, A.; Hackett, S.; Bell, W.; Green, W.; Campochiaro, P.A. Oxidative damage in age-related macular degeneration. Histol. Histopathol. 2007, 22, 1301-1308. [PubMed]

37. Biswal, M.R.; Ildefonso, C.J.; Mao, H.; Seo, S.J.; Wang, Z.; Li, H.; Le, Y.Z.; Lewin, A.S. Conditional induction of oxidative stress in rpe: A mouse model of progressive retinal degeneration. Adv. Exp. Med. Biol. 2016, 854, 31-37. [PubMed]

38. Pujol-Lereis, L.M.; Schäfer, N.; Kuhn, L.B.; Rohrer, B.; Pauly, D. Interrelation between oxidative stress and complement activation in models of age-related macular degeneration. Adv. Exp. Med. Biol. 2016, 854, 87-93. [PubMed]

39. Christen, W.G.; Glynn, R.J.; Sesso, H.D.; Kurth, T.; MacFadyen, J.; Bubes, V.; Buring, J.E.; Manson, J.E.; Gaziano, J.M. Vitamins e and c and medical record-confirmed age-related macular degeneration in a randomized trial of male physicians. Ophthalmology 2012, 119, 1642-1649. [CrossRef] [PubMed]

40. Souied, E.H.; Delcourt, C.; Querques, G.; Bassols, A.; Merle, B.; Zourdani, A.; Smith, T.; Benlian, P. Oral docosahexaenoic acid in the prevention of exudative age-related macular degeneration: The nutritional amd treatment 2 study. Ophthalmology 2013, 120, 1619-1631. [CrossRef] [PubMed] 
41. Dawczynski, J.; Jentsch, S.; Schweitzer, D.; Hammer, M.; Lang, G.E.; Strobel, J. Long term effects of lutein, zeaxanthin and omega-3-lcpufas supplementation on optical density of macular pigment in amd patients: The lutega study. Graefes Arch. Clin. Exp. Ophthalmol. 2013, 251, 2711-2723. [CrossRef] [PubMed]

42. Zhang, C.; Li, C.; Chen, S.; Li, Z.; Jia, X.; Wang, K.; Bao, J.; Liang, Y.; Wang, X.; Chen, M. Berberine protects against 6-ohda-induced neurotoxicity in pc12 cells and zebrafish through hormetic mechanisms involving pi3k/akt/bcl-2 and nrf2/ho-1 pathways. Redox Biol. 2017, 11, 1-11. [CrossRef] [PubMed]

43. Zhang, W.; Su, X.; Gao, Y.; Sun, B.; Yu, Y.; Wang, X.; Zhang, F. Berberine protects mesenchymal stem cells against hypoxia-induced apoptosis in vitro. Biol. Pharm. Bull. 2009, 32, 1335-1342. [CrossRef] [PubMed]

44. Tan, Y.; Tang, Q.; Hu, B.-R.; Xiang, J.-Z. Antioxidant properties of berberine on cultured rabbit corpus cavernosum smooth muscle cells injured by hydrogen peroxide. Acta Pharmacol. Sin. 2007, 28, 1914-1918. [CrossRef] [PubMed]

45. Li, W.; Liu, Y.; Wang, B.; Luo, Y.; Hu, N.; Chen, D.; Zhang, X.; Xiong, Y. Protective effect of berberine against oxidative stress-induced apoptosis in rat bone marrow-derived mesenchymal stem cells. Exp. Ther. Med. 2016, 12, 4041-4048. [CrossRef] [PubMed]

46. Song, D.; Song, J.; Wang, C.; Li, Y.; Dunaief, J.L. Berberine protects against light-induced photoreceptor degeneration in the mouse retina. Exp. Eye Res. 2016, 145, 1-9. [CrossRef] [PubMed]

47. Barot, M.; Gokulgandhi, M.R.; Mitra, A.K. Mitochondrial dysfunction in retinal diseases. Curr. Eye Res. 2011, 36, 1069-1077. [CrossRef] [PubMed]

48. Musat, O.; Ochinciuc, U.; Gutu, T.; Cristescu, T.; Coman, C. Pathophysiology and treatment of armd. Oftalmologia 2012, 56, 45-50. [PubMed]

49. Feher, J.; Kovacs, B.; Kovacs, I.; Schveoller, M.; Papale, A.; Gabrieli, C.B. Improvement of visual functions and fundus alterations in early age-related macular degeneration treated with a combination of acetyl-l-carnitine, n-3 fatty acids, and coenzyme q10. Ophthalmologica 2005, 219, 154-166. [CrossRef] [PubMed]

50. Feher, J.; Papale, A.; Mannino, G.; Gualdi, L.; Gabrieli, C.B. Mitotropic compounds for the treatment of age-related macular degeneration. Ophthalmologica 2003, 217, 351-357. [CrossRef] [PubMed]

51. Martins, R.; Pinto Rolo, A.; Soeiro Teodoro, J.; Furtado, E.; Caetano Oliveira, R.; Tralhão, J.; Marques Palmeira, C. Addition of berberine to preservation solution in an animal model of ex vivo liver transplant preserves mitochondrial function and bioenergetics from the damage induced by ischemia/reperfusion. Int. J. Mol. Sci. 2018, 19, 284. [CrossRef] [PubMed]

52. Gomes, A.P.; Duarte, F.V.; Nunes, P.; Hubbard, B.P.; Teodoro, J.S.; Varela, A.T.; Jones, J.G.; Sinclair, D.A.; Palmeira, C.M.; Rolo, A.P. Berberine protects against high fat diet-induced dysfunction in muscle mitochondria by inducing sirt1-dependent mitochondrial biogenesis. Biochim. Biophys. Acta 2012, 1822, 185-195. [CrossRef] [PubMed]

53. Liu, P.; Dong, J. Protective effects of carnosic acid against mitochondria-mediated injury in h9c2 cardiomyocytes induced by hypoxia/reoxygenation. Exp. Ther. Med. 2017, 14, 5629-5634. [CrossRef] [PubMed]

54. Yu, W.; Sheng, M.; Xu, R.; Yu, J.; Cui, K.; Tong, J.; Shi, L.; Ren, H.; Du, H. Berberine protects human renal proximal tubular cells from hypoxia/reoxygenation injury via inhibiting endoplasmic reticulum and mitochondrial stress pathways. J. Transl. Med. 2013, 11, 24. [CrossRef] [PubMed]

55. Lee, Y.S.; Kim, W.S.; Kim, K.H.; Yoon, M.J.; Cho, H.J.; Shen, Y.; Ye, J.M.; Lee, C.H.; Oh, W.K.; Kim, C.T.; et al. Berberine, a natural plant product, activates amp-activated protein kinase with beneficial metabolic effects in diabetic and insulin-resistant states. Diabetes 2006, 55, 2256-2264. [CrossRef] [PubMed]

56. Domenech, E.; Maestre, C.; Esteban-Martinez, L.; Partida, D.; Pascual, R.; Fernandez-Miranda, G.; Seco, E.; Campos-Olivas, R.; Perez, M.; Megias, D.; et al. Ampk and pfkfb3 mediate glycolysis and survival in response to mitophagy during mitotic arrest. Nat. Cell Biol. 2015, 17, 1304-1316. [CrossRef] [PubMed]

57. Wu, S.B.; Wei, Y.H. Ampk-mediated increase of glycolysis as an adaptive response to oxidative stress in human cells: Implication of the cell survival in mitochondrial diseases. Biochim. Biophys. Acta 2012, 1822, 233-247. [CrossRef] [PubMed]

58. Alexander, A.; Walker, C.L. The role of $1 \mathrm{kb1}$ and ampk in cellular responses to stress and damage. FEBS Lett. 2011, 585, 952-957. [CrossRef] [PubMed] 
59. Turner, N.; Li, J.Y.; Gosby, A.; To, S.W.; Cheng, Z.; Miyoshi, H.; Taketo, M.M.; Cooney, G.J.; Kraegen, E.W.; James, D.E.; et al. Berberine and its more biologically available derivative, dihydroberberine, inhibit mitochondrial respiratory complex i: A mechanism for the action of berberine to activate amp-activated protein kinase and improve insulin action. Diabetes 2008, 57, 1414-1418. [CrossRef] [PubMed]

60. Xia, X.; Yan, J.; Shen, Y.; Tang, K.; Yin, J.; Zhang, Y.; Yang, D.; Liang, H.; Ye, J.; Weng, J. Berberine improves glucose metabolism in diabetic rats by inhibition of hepatic gluconeogenesis. PLOS ONE 2011, 6, e16556. [CrossRef] [PubMed]

61. Yao, J.; Bi, H.-E.; Sheng, Y.; Cheng, L.-B.; Wendu, R.-L.; Wang, C.-H.; Cao, G.-F.; Jiang, Q. Ultraviolet (uv) and hydrogen peroxide activate ceramide-er stress-ampk signaling axis to promote retinal pigment epithelium (rpe) cell apoptosis. Int. J. Mol. Sci. 2013, 14, 10355-10368. [CrossRef] [PubMed]

(C) 2018 by the authors. Licensee MDPI, Basel, Switzerland. This article is an open access article distributed under the terms and conditions of the Creative Commons Attribution (CC BY) license (http:/ / creativecommons.org/licenses/by/4.0/). 